Cengiz BEKTAŞ

Mimar Sinan Güzel Sanatlar Üniversitesi

Mimarlık Fakültesi

Şehir ve Bölge Planlama Bölümü

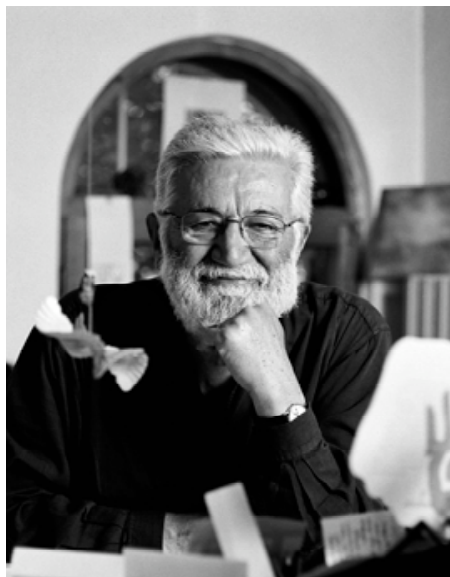

\title{
Ev, Saray, Köşk ve Kasırlar
}

\section{Evler}

İnsan, yerleşik düzene geçmeden önce geçici barınaklar yapmıştı. Mamut gibi iri hayvanların dişlerinden, kemiklerinden, kürklerinden yararlanmıştı bunun için... Ya da 1lıman iklimi olan yerlerde ağaç dallarından, yapraklarından yararlandı.

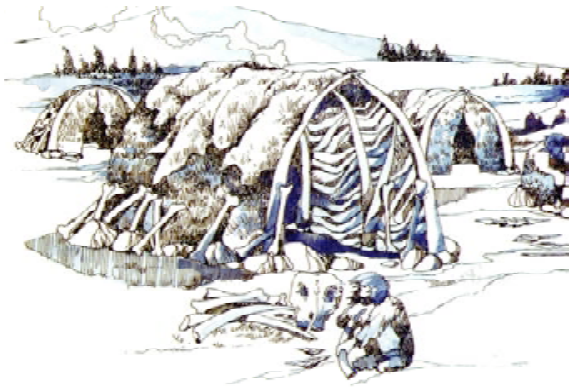

Resim: 1

\section{Neolitik Dönem}

Bugünkü bilgilerimizle, toprağın ilk işlendiği, buna bağlı olarak da ilk yerleşmenin gerçekleştiği yer Diyarbakır'la Elazı ̆̆ arasında, Ergani'den 6 km. uzaklıktaki Çayönü'dür.

Çayönü, Hilar suyunun kıyısındadır. Prof. Dr. Halet Çambel ile Prof. Dr. Robert Braidwood kazıp ortaya çıkarmışlardır. Sulanması kolay düzlük bir alandadır. Yapılar sudan, nemden korunmak için taştan bir subasman üzerine oturtulan kerpiç duvarlarla yapılmışlardır.

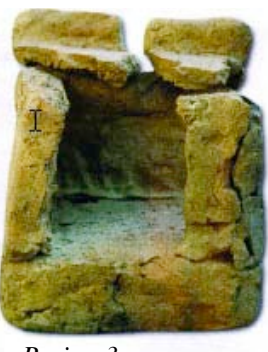

Resim: 3
Resim: I

Hayvan kemiklerinden yapilan

barinaklar.

Resim: 2

Ağaç dallarından yapılan barinaklar. (Sey, 1999, 3)

Resim: 3

Çayönü çamurdan ev maketi. (Özdoğan - Başgelen, 2007, 73)
Kerpiçin Çayönü'ndeki boyutları 40 x 40 x 10 (ana) ile 20 x 40 x 10 (kuzu) dur. Çayönü'nde kerpiç, kapı, kumilya duvarı (çatının çevresini çeviren yarım kerpiç kalınlığındaki alçak korkuluk duvarı), çörten (çatı suyunu akttmak için bıraklan yarı) ve mozaiğe benzeyen döşeme kaplaması gibi yapı ayrıntıları saptanabilmektedir.

Prof. Dr. Ufuk Esin'in kazılarıyla ortaya çıkarılan Aşıklıhöyük'ün de Çayönü ile eş yaşta olduğu belirlenmiştir. Bu evrede birleşmelerin kolaylaşması için ev tasarları, yuvarlaklıktan dörtgene dönmüştür. Kadının ağaç dallarını örüp üzerine çamur sıvayarak çanak yapması gibi, duvarlar da dallarla örülüp üzerleri sıvanarak yapılmıştır.

\section{Bakır Çă}

İlk kuruluşu 9400 yıl öncesine varan Çatalhöyük'de evler düz damlıdır. İçlerine damdaki delikten merdivenle inilerek girilir. Bu delikten hava, ş̧ık alırlar... Hemen altında yakılan 
ateşin dumanı buradan çıkar... Ateşin yandığı yer mutfak olarak kullanılan merdiven altıdır. Buradan çıkan duman, ev içini sinekten korur. Uzun evrede sıtma en önemli yıkımdır çünkü...

Bir ana oylumdan, bir de onun arkasındaki kilerden oluşur ev. Ana oylum, işlevlere göre, duvar kıyılarına sıralanmış minderler gibi bölümlenmiştir. Tapınma yeri olarak görülebilecek boğa boynuzları ile süslenmiş duvarda doğum yapan kadın (Ana Tanrıça) kabartması vardır. Baş köşedeki dörtgen bölüm en yüksek yerdir. Buraya gömü de yapılır. Ortada üretim vardır...

Doğal camdan (obsidiyen) aygıtlar yapılır burada... Duvarlarda av görüntüleriyle resimler vardı. Düz damlarında da insan çalışmaktadır, kimi işlerini uygun havalarda burada görmektedir.

Çatalhöyük evinin döşemesi de topraktı... Üzerinde dolaşıla dolaşıla ufalanıyordu. Her dönem yeniden çamurla sıvanırdı. Böylece döşeme yükselerek, evin içinde ayakta durulamaz olurdu. Bu durumda evin duvarları yarı bellerinden yıkılarak evin içi doldurulur, üzerine yeni bir ev kurulurdu. Bu yeni bir yerleşme demektir. Bu yeni doku eskisinin üzerine kurulduğu için yerleşme git gide yükselir. Bu yükseltiye "höyük" diyoruz. Çatalhöyük'te 18 katman, Troya'da 9 katman, Beycesultan'da 42 katman saptanabiliyor. Çatalhöyük, düz alandan 21 metre yüksekliktedir. Çatalhöyük'de birbirine bitişik evlerin arasında yer yer boşluklar var. Buralar çöplüktü... Belki insanın, hayvanın dışkılama yeri olarak da kullanıliyordu.

Canhasan'da, Hacılar'da iki katlı çözümler başladı. Altta ahır vardı. Üst kat yaşam alanıyd1...

Son yıllarda yapılan kazılar Anadolu'nun, Neolitik dönemin odağını oluşturduğunu ortaya koymuştur. Bakır çağında Troya, Yortan, Beycesultan (Denizli), Yumuktepe (Mersin) ve Kutsal Ayça (Hilâl) en önemli yerlerdi. Beycesultan'da M.Ö. 3000'de ilk megaron (dikdörtgen büyük bir oylumun önünde iki yanı kapalı önü açık bir giriş bölümü olan yapı türü) görülüyor. Dörtgen ana oylumun tavanının ortasında bir delik vardır. Deliğin tam altında, damı tutan 4 direğin arasında ateş yakma yeri vardır. Bütün bunlar Çatalhöyük'ü anımsatır...

Önceleri megaronun ilk örneğinin M.Ö. 1500'lerde Girit'te, Miken'de bulunduğuna inanıliyordu. Oysa Prof. Dr. Mükerrem Anabol M.Ö. 3000'de Beycesultan'da gerçekleştirilmiş megaronu ortaya çıkardı.

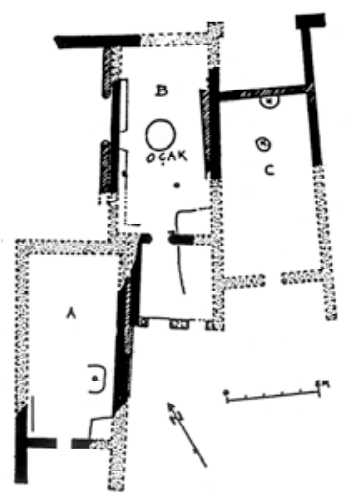

Resim: 5

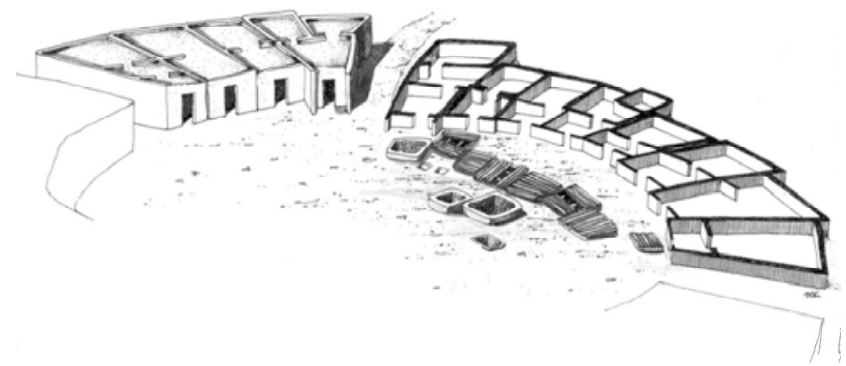

Resim: 6

2 Sayı 13, 2012 
Resim: 7 Troya'da megaron.

(Sey, 1999, 35)

Resim: 8 çifte megaron (Sey, 1999, 49)

Resim: 9 Troya'dan megaron (M. O. 3000).

Resim: 10 Troya'dan tapinak olarak kullanilan megaron (duvarların üzeri ytongla, yeni kerpiçlerle korunmuş).

Resim: ॥ Priene, avlulu ev

(Sey, 1999, 59)

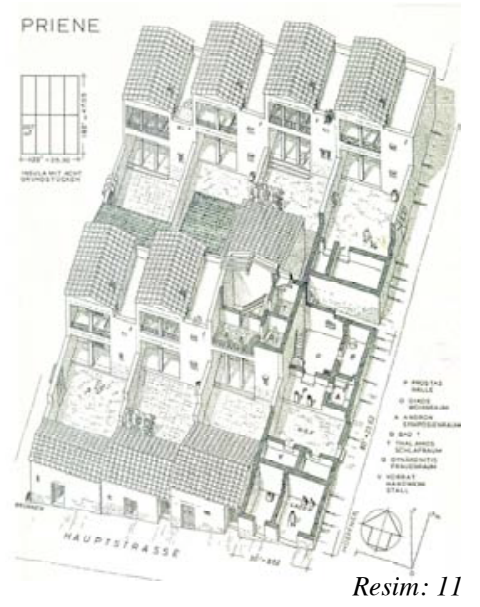

Örneğin Demircihöyük'de de (M. Ö. 3000) megaronlar bir çemberi oluşturacak biçimde sıralanmışlardır... Arka duvarları savunmayı sağlamak için kalın tutulmuştu...

Karataş / Semayük'de de M.Ö. 3000'lerden, İlk Tunç Çă̆ı'ndan megaronlar vardır. Troya'daki megaronlar ise (M. Ö. 2500 - 2200) boyutlarıyla çok büyüyerek "saray”laşırlar.
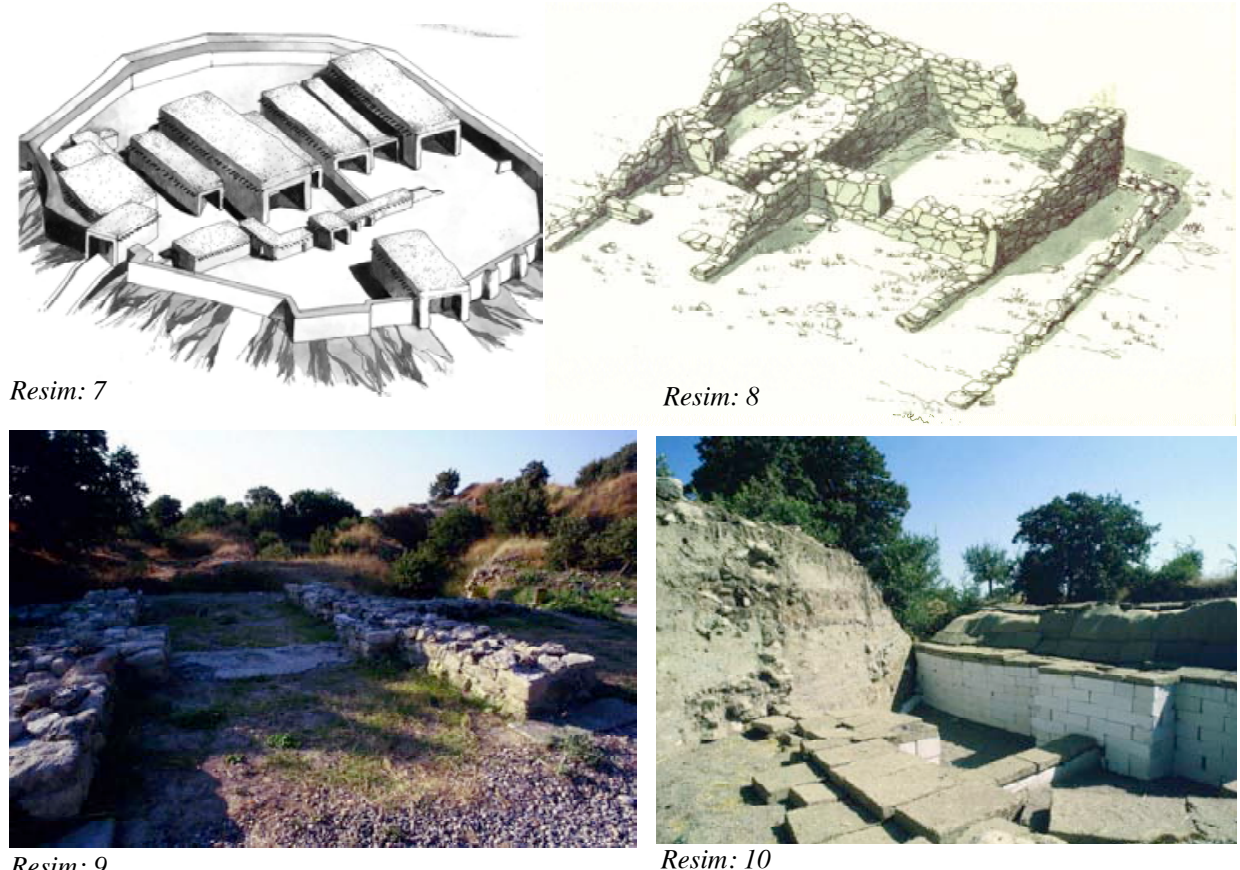

Resim: 9

Troya'da Prof. Dr. Manfred Korfman'ın bulduğu megaron, içindeki sunularıyla birlikte ortaya çıkmıştır. Bu buluntu, megaron çözümünün, tapınağın da öncülü olduğunu kanitladi.

Özetle; konut ile tapınağın kökenlerinin yurdumuzda olduğunu iç erinciyle söyleyebiliriz. M.Ö. 7. yüzyıldandan sonra Batı Anadolu'da megaron çözümü başattır. Bu çağda Eski İzmir'de "çifte megaron" bulundu. Bu çözümde yanyana iki megaron bir çatı altındadır... İki katlı, çok odalıdır... Daha sonra ortaya çıkan prostaslı evlerin de öncülüdür. Ege'de megaron, eklenen odalarla çeşitlenir.

Yeryüzünde bugünkü bilgilerimize göre ilk yerleşme Çayönü Anadolu'dadır. İlk megaronun yaratıldığı yer Anadolu'dur. Megaronun tapınağa evrildiğgi yer Anadolu'dur.

\section{Priene / Avlulu Ev}

Miletos'lu Hippodamos, daha önce kimi kuralları uygulanmış ızgara düzenli kentin belli ilkelerini saptar. Bir araya getirir... M.Ö. 5. yüzyllda Priene bu ilkelerle yoktan var edilir. Bu bir ilktir. Priene'de, kentli sayılanların eş büyüklükte parselleri vardı. Evlerin konumları, büyüklükleri de eşittir. Demokrasi ilkesi denilebilecek bu durum ne var ki yalnız kentli sayılanlar içindir. Toplumun neredeyse dörtte üçünün (kölelerin, görevlilerin, hizmetlilerin $v b$.) bu demokraside yerleri yoktu...

Etkileri Batıda da günümüze dek süren Priene'deki ev türü avluludur. Bu avluya egemen olan, önünde prostası (bir tür hayat) ile oturma odasıdır (oikos).

Oturma odasının bir yanına banyo olarak kullanıldığı düşünülen bir oylum, hayata da (prostasa) erkekler için söyleşi, şölen (sympozion) odası (andron) eklenir. Avlunun öteki yan- 
larına da, işlik, depo gibi kimi hizmet odaları eklenir.

Özellikle avlu, iklimimizin gerektirdiği çok önemli bir ögedir. Bugün yeteri güneşi olmayan kuzey ülkelerinde bile bu çözüme öykünülmektedir. Bu çözüm ayrıca açık (ışık), yarı açık (yarı ışı), kapalı (ışıksız) oylumların dengesini de sağlar... Geçişlerde gözün ışı̆̆a uyumu kolaylaşır.

\section{Peristilli Ev}

M.Ö. 3. yüzyılda, Helenimsi (Helenistik) dönemde, ilk izleri Priene'de görülen “peristilli ev" çözümü başattır. Bu tür, varsılların oturabileceği evdir... Bir avlunun çevresine önce direkler, sonra gezenek, ondan sonra da odalar sıralanmıştır. Eninde sonunda bu da "avlulu ev" çözümüdür. Çözüm daha çok Anadolu'nun Roma egemenliğinde olduğu dönemde görülür. Örneğin, Perge'de, Doğu Roma'da (Bizans'ta), sonra da Osmanlı döneminde İstanbul, tüm taşraya yaşama kültürü dağıtır. İstanbul “kent”tir. Doğu Roma döneminde Eskil (Antik) Çă̆'ın yaşama biçimi bir yere dek etkilidir. Ancak eskil kentlerin küçülmelerinden de anlaşılacağı gibi, yoksullaşma başlamıştır. Tek tanrıcılık, çok tanrıcılı̆̆ı dinsizlik saydığı için, geçmiş çağdan kalanları yok etmeğe çalışmışsa da avlulu çözümden pek ayrılınmamıştır.

\section{Selçuklu Dönemi}

Bizans kentiyle Selçuklu kenti kavramlarını ayırt edebilmek zordur. Selçuklu var olanın, önünde bulduğunun içine kaynamıştır bir anlamda. Tüm etkilenmelerini bir senteze yuğurmayı bilmiştir. Selçuk ile Doğu Roma günlük yaşama biçiminde "kerevet" ortaktır. Kentlerde İslamın getirdiği, "yıkanma” zorunluğu, Hristiyanla Müslüman evlerinde en önemli ayrımdır. Hıristiyan mahalle hamamına giderken, Müslüman yunmalık çözümünü odasına dek sokmuştur.

Kırsal kesimde varlığa göre tek ya da iki katlı ev, duvarlarla çevrili bir bahçe içindedir. Hizmet bölümleri (yıkanma yeri, mutfak, depolar vb.) bahçededir.

Varlıklıların taştan kule evleri yanında yoksulların bir ya da iki odalı barakamsı evleri

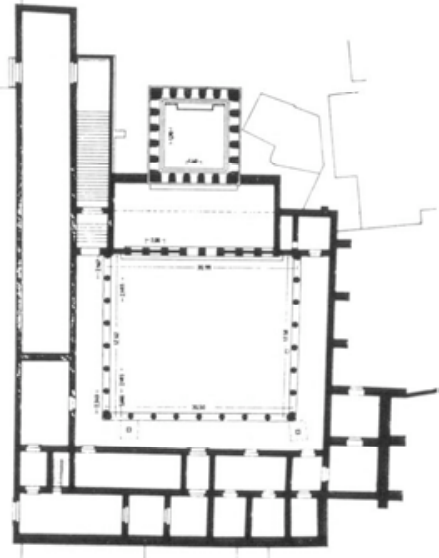

Resim: 12 sürer... Yerleşiklerin kasabasıyla, göçebelerin kırsal yerleşmesi arasında bir denge oluşur. Bu bir iş bölümünü de getirir. Birinciler daha çok zanaatla uğraşırken, ikinciler kasabanın pazarına yă̆, peynir, yoğurt, et vb. gibi çiftçiliğe, hayvancılı̆̆a dayalı ürünleri getirirler. Yerleşik olmayanların topak evleri (yurt), karaçadırları, alaçıkları son çağlara dek

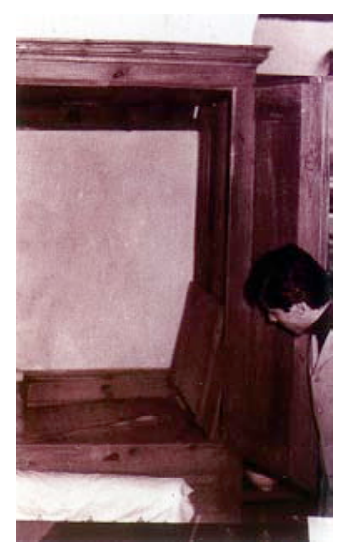

Resim: 13

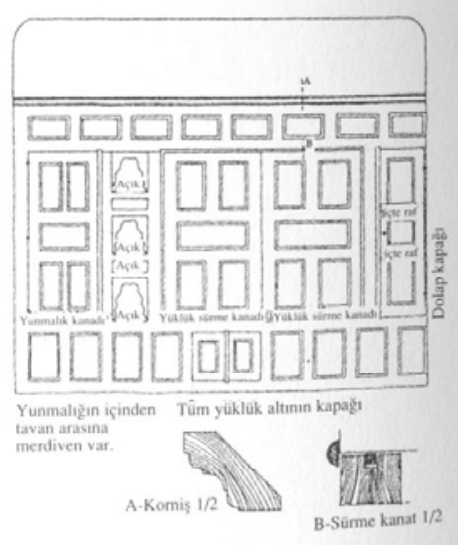

Resim: 14

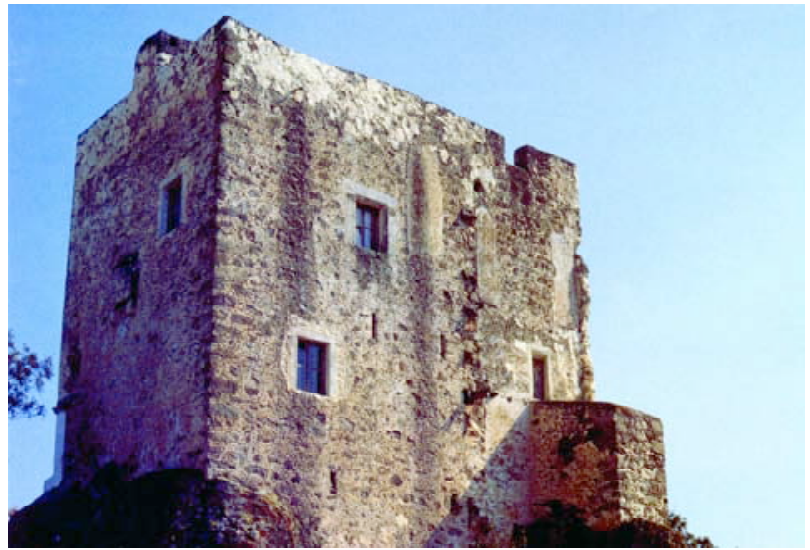

Resim: 15
Resim: 12

Bergama'da peristilli ev (saray) planı. (Akurgal, 1978, 75)

Resim: 13

Yunmalık. (Bektaş, 2007, 154)

Resim: 14

Yunmalık kapağı. (Bektaş, 2007, 154)

Resim: 15

Bodrum, Müskebi'de kule-ev. (sey, 1999, 133)

$4 \mid \operatorname{sayı13,2012}$ 


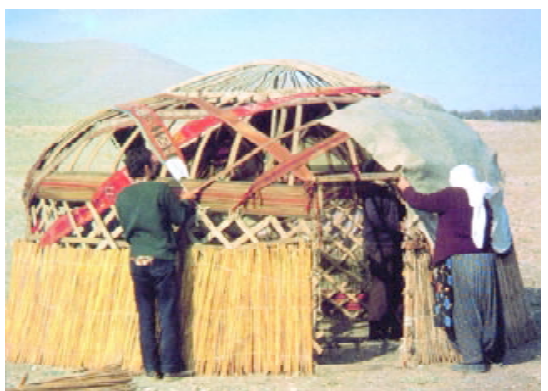

Resim: 16

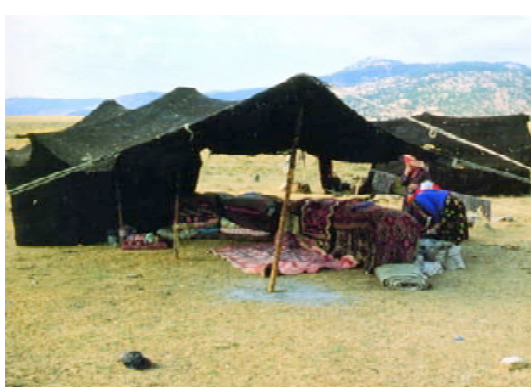

Resim: 17

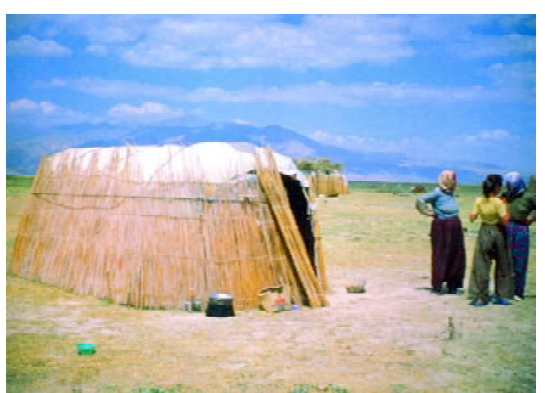

Resim: 18

Resim: 16 sürmüştür.

Topak ev.

Resim: 17

Karaf̧adir.

Resim: 18

Alaçık.

(sey, 1999, 113)

Resim: 19

Manavgat. (Belen, 1999)
Bütün Akdeniz kıyılarında olduğu gibi yazın yaylaya göçme, kışları ise kıyıdaki (ovadaki) evinde kalma gibi bir yaşama biçimi Anadolu'da da sürdürülmüştür. Yayladaki ev yazın nem, sıcaklık açısından daha iyi yaşama ortamı sağlar. Bu bir yandan da kışa hazırlıkların yapıldığg1 evredir.

Geçici olarak kullanılan ama kendileri geçici olmayan yapılardan oluşan yayla

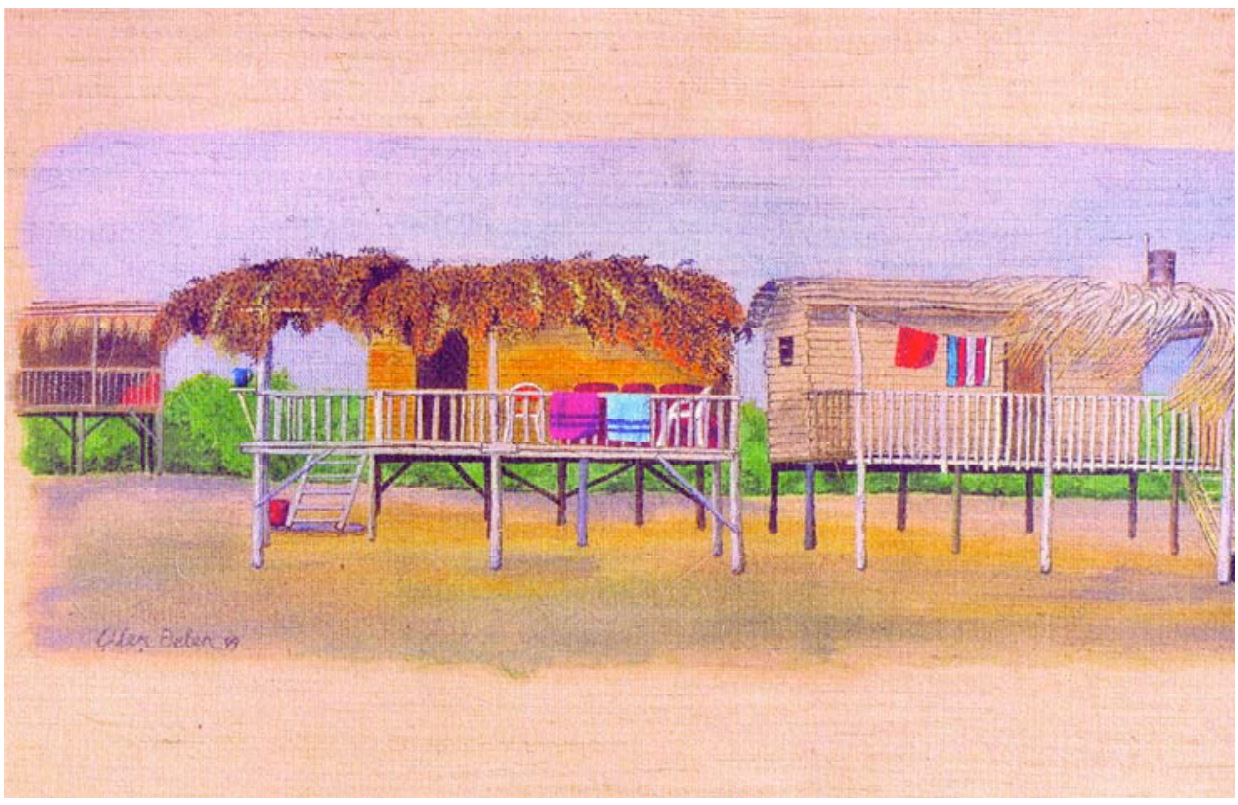

Resim: 19

yerleşmesinin Manavgat kıyısında, Bolu dağlarında, Doğu Karadeniz’de olduğu gibi, Anadolu'da ilginç, nitelikli örnekleri vardır.

\section{Osmanlı Dönemi}

Osmanlı sarayının, ayrıca İstanbul'u örnek alan Edirne, Bursa, Manisa, Amasya gibi yönetim özeklerinin yönetici konutlarının bir iç bölümü bir de dış bölümü vardır. Konutun "iç" bölümü özel yaşam içindir: Harem. "Dış" bölüm ise bir yönetim birimidir: Selamlık... Selamlık kamuya açıktır...

İstanbul'da "hücre”, “oda" denilen tek katl1, tek odalı (tuvalet, su kullanımları ortak) konutlar, Doğu Roma'da da, Osmanlı'da da alt gelirlilerin barınma biçimidir. 


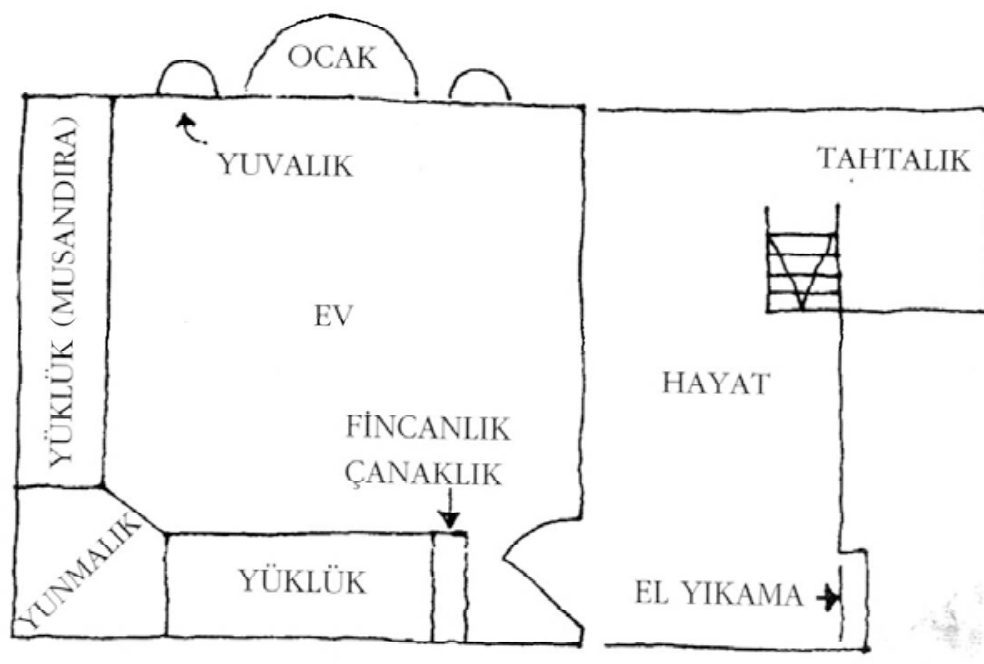

Resim: 20

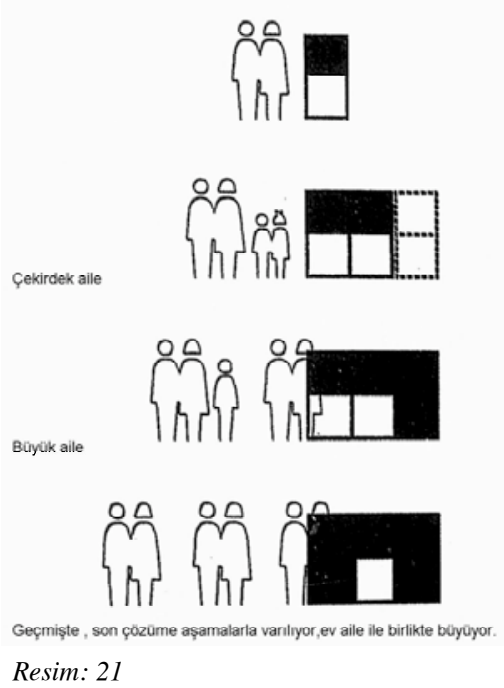

Resim: 21

Osmanlı döneminde bizim "oda" dediğimiz birime "ev" denmektedir. Bir ev ya da oda, bir çekirdek aileyi barındırır. Oda iki bölümlüdür. Bir seki altı, bir de bir basamak daha yüksek olan seki vardır...

Seki ana ögedir. Bir ocağı, oturma sedirleri vardır. Hem oturma odasıdır, hem de yemek yenir, yatılır; abdest alınır, namaz kılınır. Seki altında, yüklük vardır (yatakların, yorganların yastıkların konduğu, onların ölçülerine uygun büyük dolap) fincanlık vardır, taş dolap, odunluk, yunmalık vardır. Hepsi bir dolap gibi duvara sıralanırlar. Oda kapısı seki altına açılır... Kapı açılınca hemen içerisi görülmeyecek gibi düzenlenmiştir.

Oda'nın sayısı, önündeki "hayat"1, avlusu, bahçesiyle birlikte önce tektir. Sonra aile Resim: 20

Oda planı. (Bektaş, 2005, 45)

Resim: 21

Geçmiste, son fözüme aşamalarla variliyor, ev aile ile birlikte

büyüyor. (Bektaş, 2005, 44)

Resim: 22

Türkiye'nin bitki örtüsü haritası. (Bektas, 2007, 49) büyüdükçe (çocuklar yetiştikçe) sayıları artar. Daha da sonra bölünmesi de olanaklıdır. Ev aileyle birlikte büyüyebiliyor. Ya da sonradan bölünebiliyor...

Büyük evlerde, konaklarda şöyle bölümler de olurdu: Namaz, kitaplık, arz, divan odası gibi...

\section{Yüzyıl}

19. yüzyılda Osmanlı yaşama kültürü üst düzeye ulaşır. İstanbul'da üretilen yaşama kültürü taşraya örneklik eder. Gene de taşra kendi kültürünü ona katmayı bilir.

Bütün yörelerde ilke birliği vardır. Yapı gereci açısından durum şöyledir;

- Yeterli yağış alan yerlerde yeşil dokunun, ağaç varsıllığının sonucu, yapı gereci olarak

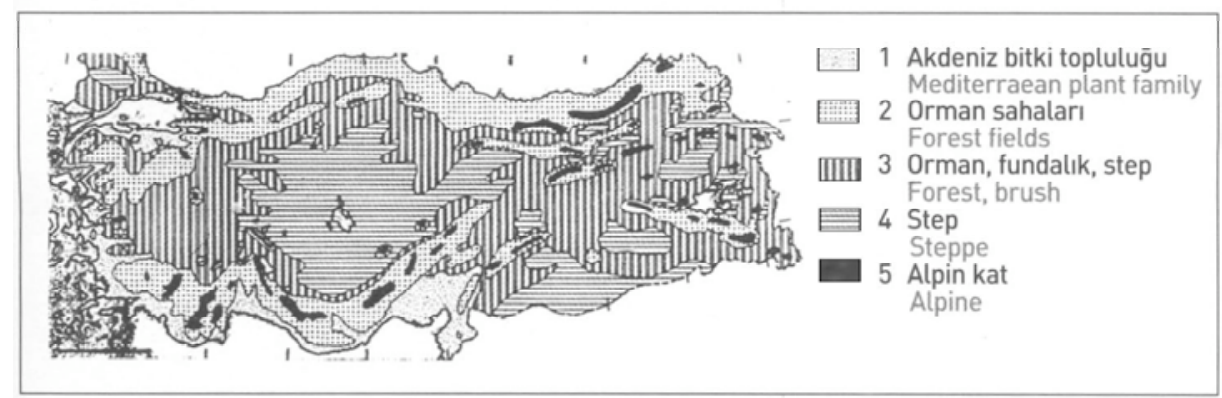




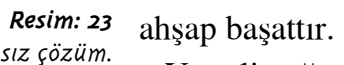

Tasar tipleri: sofasız f̧özüm. (Bektas, 2007, 144)

- Yeterli yağış almayan, ancak taşça varsıl yörelerde yapı gereci taştır.

- Taşın bile olmadığı yörelerde yapı gereci topraktır.

Resim: 24 Tasar tipleri: L sofalı f̧özüm.

(Bektass, 2007, 146)

- Bunların belli bir dengede var olduğu yörelerde karışık gereç kullanımı, yapım yöntemi geçerlidir.

Resim: 25 Tasar tipleri: if sofalı f̧özüm.

(Bektas, 2007, 148) Yalnızca varsılların konutlarını düşünerek değil de, ortalama olarak bakıldığında Türkiye

Resim: 26 evlerinin ortak ilkelerini şöyle sıralayabiliriz.

Tasar tipleri: dış sofalı I çözüm. - Yaşama (-insana), doğaya, çevre koşullarına uygunluk, saygı...

(Bektas, 2007, 145) - Doğanın kan dolaşımı içinde olmak... Havayı, suyu, toprağı kirletmemek...

Resim: 27 - Gerçekcilik, akılcılık...

Tasar tipleri: dış sofalı U çözüm. • İçten dişa çözüm...

(Bektaş, 2007, 147) - Önce "iç”in (özün, işlevin) çözümü; dişın buna göre uyumla biçim alması...

Resim: 28 •İ̇c’le "diş”1n uyuşumu... Yalan söylememek...

Tasar tipleri: orta sofalı çözüm. (Bektas, 2007, 149)

- Tutumsallik...

- Kolaylik...

- Ölçülerin insan bedeninden çıkması...

- Gereçlerin, yapım yönetiminin en yakından seçilmesi...

- Esneklik, kuşaklara göre değişebilme, büyüyüp, küçülebilme...

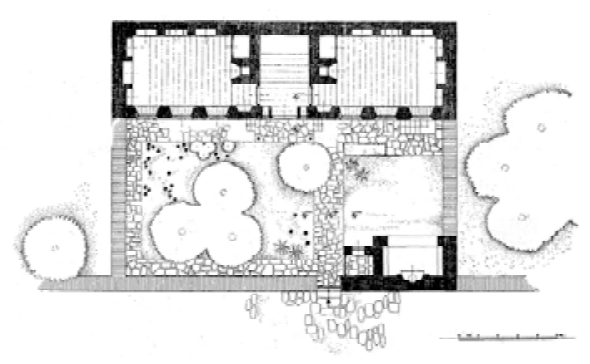

Resim: 23

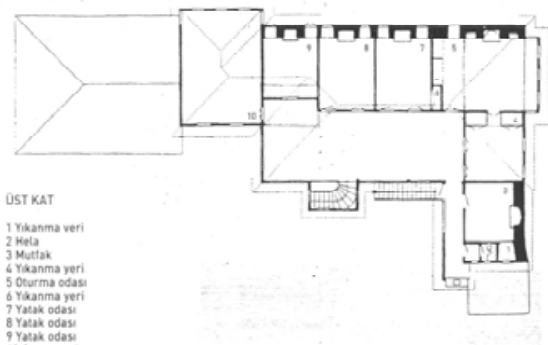

Resim: 24

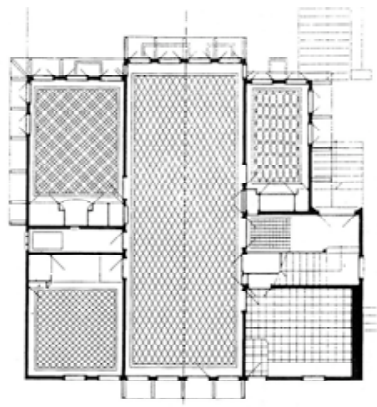

Resim: 25

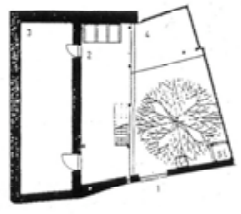

BODRUM KAT PLANI

1 Giris
2 Axtu
3 Ahit
2 Bahce
5 wis

Resim: 26

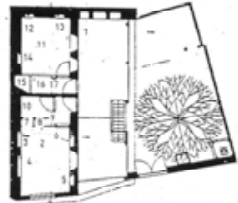

ÜST KAT PLANI

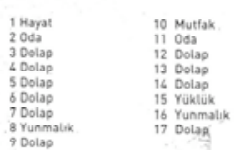

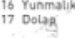

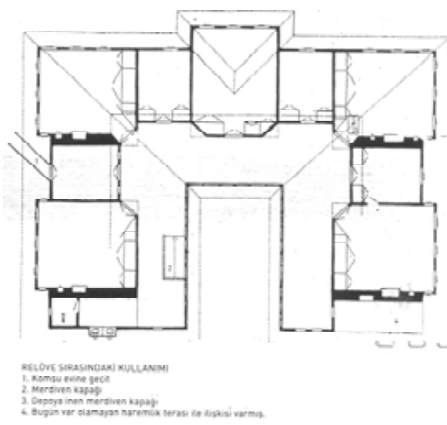

Resim: 27

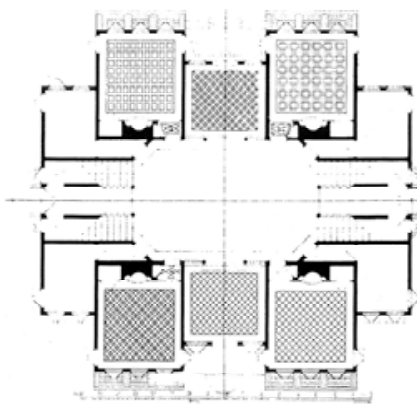

Resim: 28 
Bugün Türkiye Cumhuriyeti egemenliği altındaki topraklardaki evlere "Türk Evi" diyoruz. Bulgaristan'dakilere Bulgarlar Bulgaristan evi; Makedonyalılar Makedonya evi vb. diyorlar.

\section{Saraylar}

Türk evine, varsıllığın, olanakların en geniş olması durumuna, örneğin sultanların, sadrazamların evlerine "saray" diyoruz. Saraylar, sofalarla bölümlenmiş olarak bir bakıma gene Türk Evi ilkeleriyle gerçekleştiriliyorlar. Buna örnek olarak Dolmabahçe, Çırağan, Beylerbeyi, Arnavutköy Çifte Sarayları gösterebiliriz.

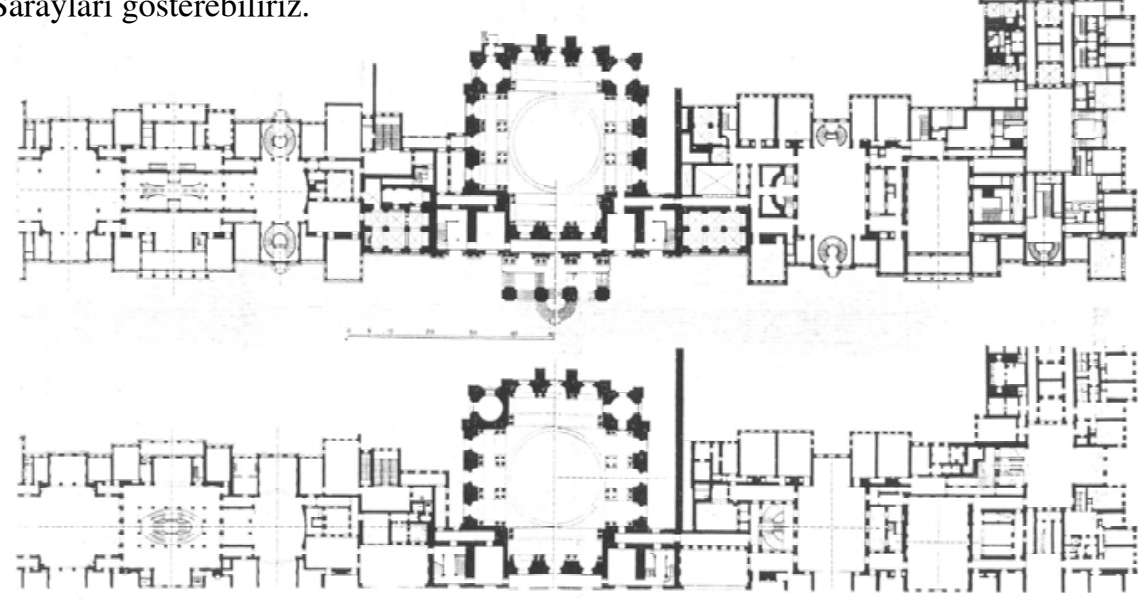

Resim: 29

\section{Köşkler}

Sarayların, konakların ya da büyük evlerin bahçelerinde, kimi kez birkaç saat, kimi kez birkaç gün kullanmak üzere yapılan yapılara "köşk" diyoruz. Bunlar yeğni gereçlerle yapılmışlardır. Ancak kâgir olarak yapılmış olanlar da vardır. Bir sarayın, konağın çok sayıda köşkü olabilir. Kimileri özel amaçlar için yapılırlar (Av köşkü gibi).

Köşklere, Çinili Köşk, Cihannüma Köşkü (Edirne), Kum Köşkü ya da Kasrı (Edirne),. Davutpaşa (İstanbul), Siyavuşpaşa Havuzlu Köşkü, Revan Köşkü, Emirgan Şerifler Yalısı Köşkü örnek gösterilebilir. Bunların da bir ev bahçesindeki kameriyeden bir saray büyüklüğüne dek çeşitleri vardır. Abdülmecid Köşkü iyi bir örnektir. Sultan Camilerindeki hünkâr mahfilleri de köşklerden sayılır.

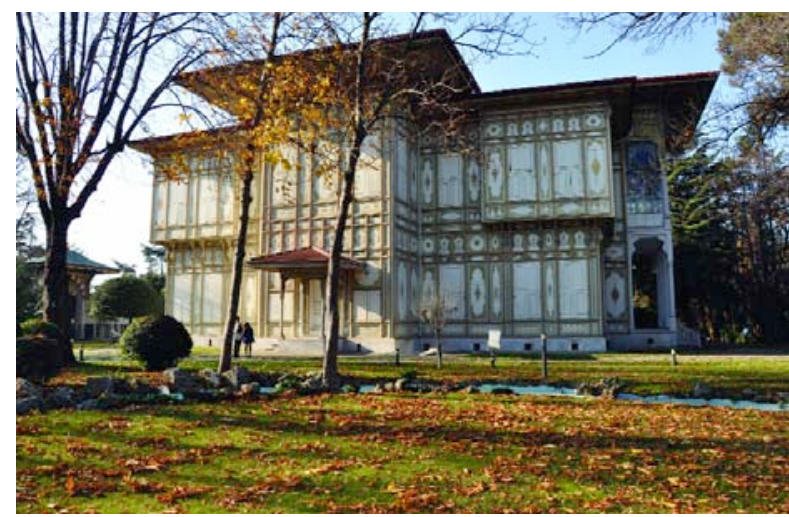

Resim: 30

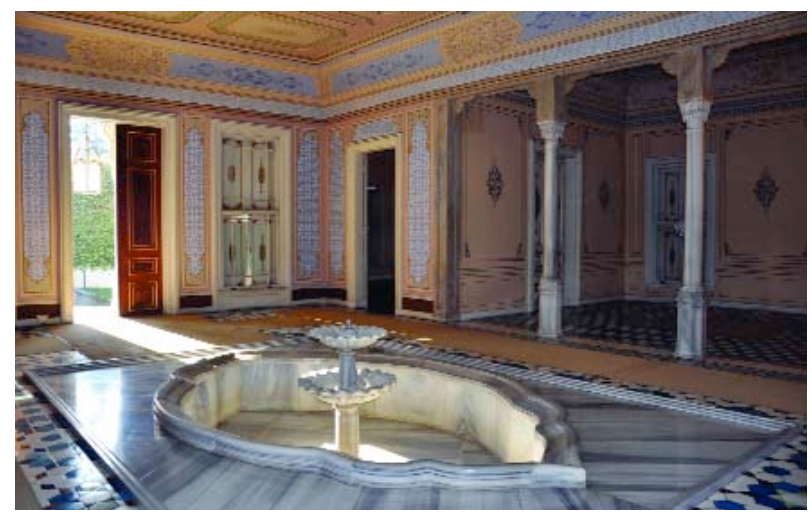

Resim: 31
Resim: 29

Dolmabahce Sarayı.

(Eldem, 1986, 146-147)

Resim: 30

Abdülmecid Köşü.

Resim: 31

Abdülmecid Köşkü, iş mekân.

Resim: 32

Mürsel Paşa, taş oda.

(Bektas, 200I, 238)

Resim: 33

S. Sirer Yalısı. (Eldem, 1982, 49)

\section{Resim: 34}

Gecekondular, Ankara. 


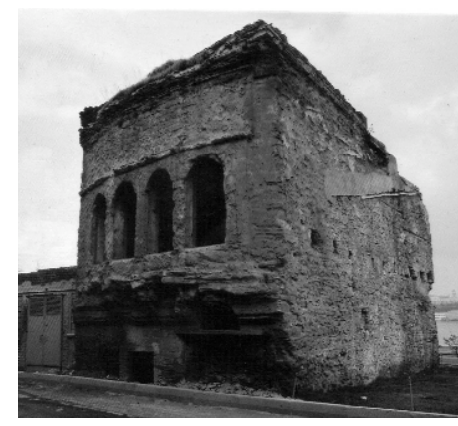

Resim: 32

\section{Kasirlar}

Köşklerin daha büyük örneklerine "kasır" denilir. Sultanahmet Camiinndeki, Yeni Cami'deki kasırlar buna örnektir. Giderek kasırlar camilerin planlarında değişmez yerlerini almışlardır. Beylerbeyi, Dolmabahçe, Tophane'deki Nusretiye, Ortaköy camilerinin kasırlarında olduğu gibi. Son evrede kışlalarda da kasırlar yapılmıştır.

\section{Taş Odalar}

Sarayların, konakların belli amaçlar için yapılmış, ana yapıdan ayırı taş odaları vardır. Taş odalar bir büyük oylumdan, onun yanında, altında, oranla, küçük hizmet oylumlarından oluşur. Yangına dayanıklı gereçlerle (kâgir) yapılırlar. Böylece yangında sı̆̆ınılacak bir yer sağlanmış olur. Bunun dışında bu odalar gizli eğlenceler, özel toplantılar için de kullanılırlardı. Bunlara örnek Mürsel Paşa'nın taş odasıdır.

\section{Cumhuriyet Dönemi}

20. yüzyılın ilk çeyreği içinde Osmanlı İmparatorluğu parçalandı. Anadolu'da kurulan Cumhuriyet, Atatürk devrimleri, toplum yaşamını değiştirdi. Daha Osmanlı döneminde Batı etkisiyle yeni yollar aranmağa başlanmıştı. Mimar Vedat Bey’in Nişantaşı'ndaki evi buna bir örnektir (I. Ulusal Mimarlik).

Cumhuriyet ile toplum yaşamının yeni düzenleyicileri, aradıklarını, bu eski çözümlerde bulamıyorlardı. O günlerde mimarlarımızın sayıları da bir elin parmaklarını geçmiyordu. Aranması sürdürülen yeni yollar için, Batı etkilenmesine, Batılı mimarlara kapılar ardına dek açıldı. Giderek onlara öncelik bile tanındı.

1930'larda en yoğun, olumlu etki Bauhaus etkisiydi.

Üstelik Almanya'nın, sosyal demokrasi kökenli bu akımının ilkeleriyle Türk Evi’nin ilkeleri çakışıyorlardı.

Ankara, İstanbul, İzmir, Adana, Bursa, Antalya gibi kentlerimizde Bauhaus etkisinde olsalar da ilginç, olgun, çağdaş evler gerçekleştirilirdi.

1932'lerde ise mimarlarımız okullarını bitirip çalışmağa başladılar. Bunlardan Sedad H. Eldem'in, Seyfi Arıkan'ın yapıtları çağdaşlığın simge işleriydi.

1940’ların özellikle 2. yarısında bu kez faşist Avrupa'nın etkisiyle bir kez daha Ulusal Mimarlık (II. Ulusal) dönemi yaşandı. Eski Türk evlerinin biçimlerinden yararlanılıyordu... 1950’lerde ülkemizde uluslararası akımın etkisi başladı. İsviçre kökenli Fransız mimar Le
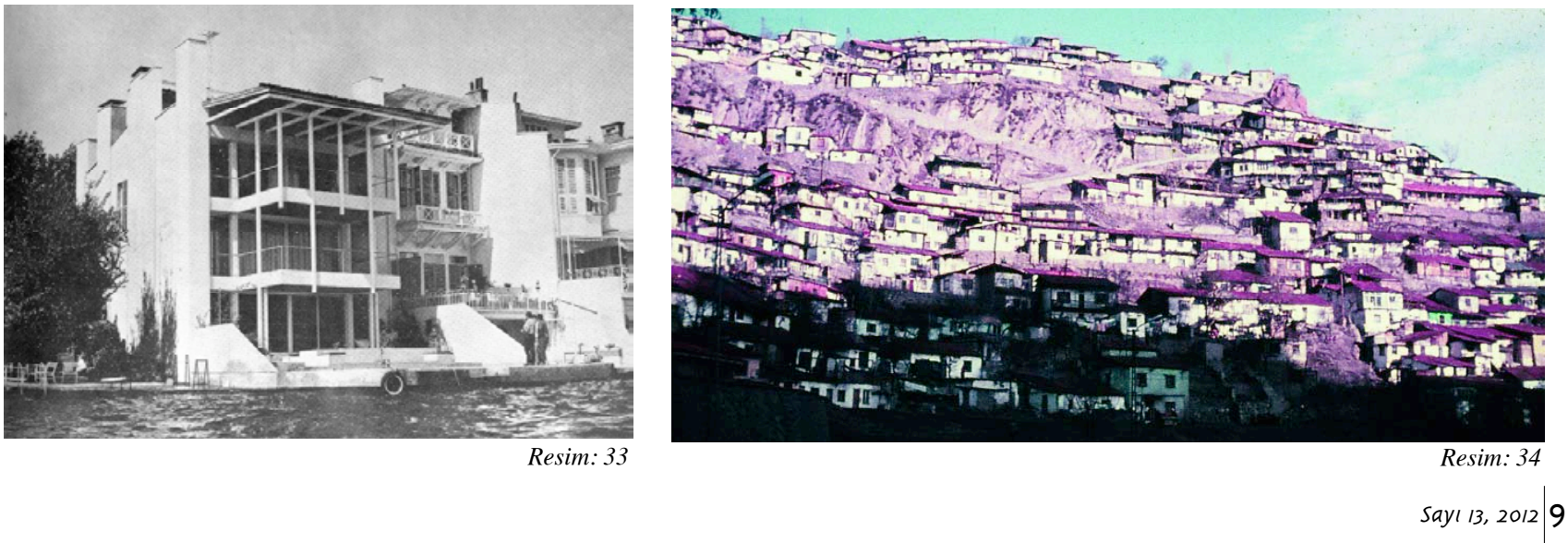
Corbusier, Brezilyalı Oscar Niemeyer gibi mimarlar moda oldu.

Varlıklılar bu evrede, yalnızca biçimlerle, çağdaşlıklarını kanıtlıyorlardı. Kültürü üretmek artık yalnız İstanbul'un işi değildi. 1960'larda konut açığının kapatılmasına çalışılıyordu. Türk yaşama kültürüne uymayan en az yarısı yanlış yönlendirilmiş konutların yan yana, üst üste yı ̆̆ılmalarından oluşan apartmanlar sardı her yanı. Bütün kentler birbirine benzedi, kendilerine özgü niteliklerini yitirdiler. Gelirleri en alt düzeyde olanlar, işin, aşın ardından kentlere göçtüler. Örneğin Ankara'nın \%73'ü gecekondulardan oluştu.

Gecekondular belediye alanlarının dışını, eğimli yerleri seçiyorlardı. Döküntü görünüşlerine karşın eski Türk kentlerinde olduğu gibi kimse kimsenin görüşünü (göz hakkını), havasını, güneşini kesmiyordu. Bir iki kök de olsa ağaçlıydılar bu konutlar. Gecekondular da, eski Türk evleri gibi tek odadan başlayıp büyüyebiliyorlar sonra da bölünebiliyorlard1.

Varlıklı kesimde, Sedad Hakkı Eldem'in eskiye dayalı, yapıtlarının az ya da çok kopyaları sürüyordu. Sonra da doğrudan Batı kopyalarına, doğrudan Batılı mimarlara iş verilmeğe başladı. Yöreseli kavrayıp, gelenekle hesaplaşarak, ona çağdaşlıkla eklenmeğe çalışanlar da vardı az da olsa...

Ne var ki hızlı yapım yöntemi kullanarak, bizim yaşama kültürümüze dayanmayan konut kitlelerini rengarenk boyayarak, yalnızca para kazanmayı düşünerek, hükümet eliyle konut üretimi aldı başını gitti. Kent planlarında denge yitirildi. Adına "kentsel dönüşüm” diyerek yapılan uygulamalar sosyolojik sorunlar yaratacak duruma geldiler

\section{Kaynakça}

Akurgal, Ekrem. 1978. Ancient Civilizations and Ruins of Turkey. Ankara: Türk Tarih Kurumu Basımevi Cengiz Bektaş kişisel arşivi

Bektaş, Cengiz. 2001. Koruma Onarım. İstanbul: Literatür Yayıncılık

Bektaş, Cengiz. 2005. Babadağ Evleri. İstanbul: Bileşim Yayınevi

Bektaş, Cengiz. 2007. Türk Evi. İstanbul: Bileşim Yayınevi

Belen, Ç. 1999. Manavgat Resim

Eldem, Sedad Hakkı. 1986. Türk Evi Osmanlı Dönemi. Türkiye Anıt Çevre Turizm Değerlerini Koruma Vakfı.

Eldem, Sedad Hakk1. 1982. Büyük Konutlar. Ankara: Yaprak Kitabevi

Özdoğan, Mehmet ve Başgelen, Nezih. 2007. Türkiye'de Neolitik Dönem Yeni Kazılar, Yeni Bulgular; Metinler. İstan-

bul: Arkeoloji Sanat Yayınları

Sey, Yıldız, der. 1999. Tarihten Günümüze Anadolu'da Konut ve Yerleşme. İstanbul: Tarih Vakfı Yayınları

Vedat Tek Sergisi Resim

Sey, Yıldız (ed.). 1999. Tarihten Günümüze Anadolu'da Konut ve Yerleşme, İstanbul: Tepe Mimarlık Kültür Merkezi. 